\title{
PROBLEM GENEZY ZORGANIZOWANEJ PRZEMOCY W ŚWIETLE ŹRÓDEL ARCHEOLOGICZNYCH
}

\author{
PROBLEM OF ORGANISED VIOLENCE IN THE LIGHT \\ OF ARCHAEOLOGICAL EVIDENCE
}

\author{
Rafat Skrzyniecki \\ Instytut Prahistorii, Uniwersytet im. Adama Mickiewicza \\ ul. Umultowska 89D, 61-614 Poznań, Poland \\ rskrzyniecki@gmail.com
}

\begin{abstract}
The problem of origins of violence in prehistory still raises many controversies among scholars representing nearly all branches of social sciences. The large number of existing interpretations only complicates the current state of research. This paper's aim is to present and briefly discuss two main theoretical approaches to the problem, along with an attempt to evaluate them using archaeological record representing the earliest material evidence for small-scale organized warfare.
\end{abstract}

KEY WORDS: theoretical approaches to prehistoric warfare, interpersonal violence, origins, Mesolithic, traumata.

Geneza konfliktów zbrojnych to jedno z bardziej kontrowersyjnych i spornych zagadnień badawczych, dyskutowanych $\mathrm{w}$ ramach szeroko rozumianych nauk o człowieku. Początkowo stanowiło ono przedmiot zainteresowania antropologii, by z czasem zagościć również na łamach debaty archeologicznej. Przez długi czas jedynym źródłem dla badań nad początkami zorganizowanej przemocy w społecznościach ludzkich były obserwacje etnografów opisujących tzw. ludy pierwotne, tj. współcześnie żyjące społeczności zbieracko-łowieckie o egalitarnej strukturze społecznej, określane w piśmiennictwie naukowym jako „przedpaństwowe”. Postępujący od lat 90. XX w. wzrost zainteresowania kwestią genezy konfliktów zbrojnych $\mathrm{w}$ archeologii stworzył zupełnie nowe, poniekąd rewolucyjne, perspektywy badawcze - pozwolił bowiem na zestawienie wyników pracy etnografów z danymi dotyczącymi funkcjonowania społeczności pradziejowych w ich pierwotnym kontekście, wolnym od wpływów cywilizacyjnych, które nierzadko wypaczały prawdziwy obraz współcześnie żyjących ludów zbieracko-łowieckich. 
W niniejszym artykule zaprezentowano i omówiono pokrótce dwa wiodące nurty badawcze dotyczące genezy konfliktów zbrojnych w społecznościach pradziejowych: pierwszy doszukuje się korzeni zjawiska zorganizowanej przemocy w naturze człowieka i postuluje jego bardzo wczesną metrykę; drugi natomiast ukazuje konflikt zbrojny jako fenomen czysto kulturowy, będący swego rodzaju produktem ubocznym procesów adaptacyjnych, prowadzących do wykształcenia się bardziej osiadłego trybu życia. Przedstawiciele obu nurtów zaciekle bronią swoich stanowisk, przytaczając coraz to nowe argumenty naukowe, w ich mniemaniu dyskredytujące przekonania adwersarzy. Dyskusja ta ma zatem dynamiczny charakter, co przekłada się na cały wachlarz interesujących hipotez badawczych promowanych przez obie strony. Problematyka konfliktów zbrojnych nadal stosunkowo rzadko jest dyskutowana na gruncie rodzimej archeologii. Istnieje zatem realna potrzeba syntezy dorobku zagranicznych badaczy zajmujących się archeologią warfare we wszystkich jej aspektach oraz aplikacji opracowanych przez nich propozycji interpretacyjnych na gruncie rodzimym - i w efekcie uzupełnienia dotychczasowej refleksji archeologicznej o kwestie związane ze zorganizowaną przemocą i wpływem, jaki wywarła ona na rozwój społeczności pradziejowych.

\section{DEFINICJA ,WOJNY PIERWOTNEJ"}

Refleksja nad genezą wojen w pradziejach wymaga podania jednoznacznej i klarownej definicji tegoż pojęcia. Jest to o tyle trudne, że w piśmiennictwie archeologicznym i antropologicznym funkcjonuje ich co najmniej kilka. Możliwe jest jednak wyróżnienie pewnej płaszczyzny wspólnej, stanowiącej swoisty merytoryczny trzon warfare, tj. rzeczonej wojny ,pierwotnej”. Na podstawie ustaleń antropologii kulturowej udało się określić pewne minimum cech definiujących wojnę $\mathrm{w}$ jej ujęciu ogólnym (niezależnie od stopnia rozwoju jednostek kulturowych biorących w niej udział). Jest to zatem ,przedsięwzięcie grupowe, skierowane na zewnątrz, przeciwko innej grupie ludzi, nie tylko przeciw pojedynczym osobom lub ich rodzinom, ale przeciw członkom całej wspólnoty, tym, którzy będą uzbrojeni, wykażą wolę użycia broni lub będą stawiać opór”. Celem tego przedsięwzięcia jest „pozbawienie życia członków zaatakowanej wspólnoty" (Buliński, Kairski 2006) lub przynajmniej branie pod uwagę potencjalnych skutków śmiertelnych działań. Jak widać, definicja ta nie uwzględnia jednostkowych zabójstw oraz tzw. wypraw odwetowych, podyktowanych zwyczajem „krwawej zemsty”.

Istotną cechą konfliktów zbrojnych doby pradziejowej jest konsekwentna realizacja zdefiniowanej przez R. Kelly'ego „zasady zastępowalności” (Kelly 2000). Polega ona na tym, że celem ataku nie są konkretne jednostki, lecz losowo wybrani członkowie wrażej grupy, w tym również kobiety i dzieci. Reguła ta wyraźnie koresponduje zarówno z przekazami etnografów, jak i materiałami archeologicznymi. 
Termin warfare nastręcza również pewnych trudności ze względu na niejednoznaczność polskiego przekładu. Zasadniczo w rodzimym piśmiennictwie naukowym pojęcia war i warfare tłumaczy się identycznie - wojna. Dotyczą one jednak dwóch odmiennych praktyk różniących się między sobą skalą oraz stopniem skomplikowania realizowanych zadań. Prawdopodobnie łatwiej przytoczyć negatywną definicję pojęcia warfare, podając tym samym, czym ono nie jest, aniżeli ustalić jego ścisły zakres znaczeniowy. W tym miejscu warto jednak umieścić cytat ze znakomitej pracy pod redakcją T. Bulińskiego i M. Kairskiego (2006), którzy sugestywnie podpowiadają, jak należy rozumieć ów termin. Jest to zatem

[...] działanie, które nie uległo optymalizacji i racjonalizacji zgodnie z nowożytnym rozumieniem tych terminów. Wystarczy je uznać za dawną formę przemocy; formę, którą jeszcze parę wieków temu znały także społeczności europejskie. Symbolem tego dawnego świata niech będzie chociażby śmierć na polu bitwy pod Crécy niewidomego Jana Luksemburskiego w roku 1346, w czasie wojny stuletniej. Aby zrozumieć motywy jego decyzji i okoliczności jego śmierci, raczej należy odwołać się do koncepcji warfare niż do nowożytnego, zracjonalizowanego modelu wojny.

\section{MROCZNE BRZEMIĘ GENÓW. PRZEMOC JAKO CECHA ADAPTACYJNA}

Od lat 60. do 90. XX w. - najpierw w ramach socjobiologii, potem zaś psychologii ewolucyjnej - systematycznie rosła liczba zwolenników koncepcji przypisującej czynnikom biologicznym nadrzędne znaczenie w procesie kształtowania się mechanizmów kulturowych w społecznościach ludzkich (Ridley 2003). Przedstawiciele psychologii ewolucyjnej wysunęli hipotezę, że wszelkie zachowania właściwe ludziom (w tym również kwestie dotyczące przemocy) kształtowały się w Środowisku Adaptacji Ewolucyjnej (z ang. EEA - Environment of Evolutionary Adaptation). Leda Cosmides i John Toby stwierdzili wręcz, że „nasze współczesne czaszki mieszczą w sobie rozum z epoki kamienia" (oryg.: "our modern skulls house a stone age mind"; por. www.psych.ucsb.edu/research/cep/primer.html). Ramy chronologiczne modelu EEA określa się na paleolit i mezolit (Pinker 1998, s. 42). I.J.N. Thorpe dystansuje się jednak od tej propozycji, zwracając uwagę na nieścisłości związane $\mathrm{z}$ wyznaczeniem zakresu przestrzennego omawianego środowiska adaptacyjnego (Thorpe 2005). Podążając dalej tropem paradygmatu psychologiczno-ewolucyjnego, należy odnieść się do kolejnych trzech wywodzących się zeń koncepcji: terytorialnej, reprodukcyjnej oraz rywalizacji o status (territorial, reproductive and status competition).

Autorem modelu terytorialnego jest E.O. Wilson (1978). Uznał on, że etnocentryzm (tj. postrzeganie własnej grupy jako nadrzędnej względem innych) jest jednym z produktów doboru naturalnego (Thorpe 2005). Jego zdaniem ludzki mózg 
„zaprogramowano” w taki sposób, że ludzie instynktownie dzielą pozostałych przedstawicieli swojego gatunku na wrogów i przyjaciół. Aby wyjaśnić istotę tego zjawiska, E. Wilson posługuje się metaforą ptaków, przyrównując ów mechanizm kategoryzacji do umiejętności nawigacyjnych czy zdolności przyswajania śpiewów terytorialnych. Idąc dalej, badacz zaznacza, że podświadomie obawiamy się intencji i działań obcych ludzi, i instynktownie sięgamy po przemoc jako podstawową metodę rozwiązywania konfliktów. Zachowania te kształtowały się w ciągu setek tysięcy lat istnienia gatunku ludzkiego, działając na korzyść osobników, które realizowały je w sposób możliwie najskuteczniejszy (Wilson 1978, s. 119). Hipoteza ta zupełnie pomija logiczne poniekąd założenie, że z perspektywy ewolucyjnej zdecydowanie korzystniejszym rozwiązaniem byłoby nawiązanie współpracy z sąsiednimi grupami, zwłaszcza w czasach wzmożonego zagrożenia ze strony drapieżników.

Propozycję Wilsona w pewnym stopniu rozwinęli Richard Wrangham i Dale Peterson (1996). Wskazali oni na ciągłość instynktu terytorialnego u ludzi, trwającą od czasów istnienia wspólnego przodka szympansów i ludzi. Instynkt terytorialny rysuje się bardzo wyraźnie wśród współcześnie żyjących prymatów, w szczególności zaś wspomnianych szympansów. Młode samce zbierają się w grupy i wspólnie patrolują obszary graniczne swojego terytorium, wdając się przy tym w krwawe walki z osobnikami zajmującymi tereny ościenne. Stawką konfrontacji jest zapewnienie sobie dostępu do zasobów środowiskowych, znajdujących się w pieczy przeciwnika. Zdaniem autorów ,współczesne szympansy są zaskakująco wiernym odpowiednikiem naszych wspólnych przodków. Wynika stąd, że prezentowane przez nie zachowania agresywne stworzyły podwaliny pod późniejsze konflikty ludzkie, czyniąc ze współczesnych ludzi skołowane niedobitki spirali przemocy trwającej od przeszło 5 milionów lat" (Wrangham, Peterson 1996, s. 63; thum. autora). R. Wrangham i D. Peterson wskazują również na podobieństwa w zachowaniu szympansów, członków amerykańskich gangów oraz Indian Yanomamo z dorzecza Amazonii. Podobnie jak poprzednia, również i ta propozycja interpretacyjna ma kilka słabych punktów. Wspomniany model bazuje głównie na obserwacji zachowań współczesnych szympansów i niejako arbitralnie zakłada, że należy je interpretować przez pryzmat wzorców właściwych populacjom ludzkim. Autorzy przyjmują wręcz, że obserwacje dotyczące prymatów stanowią bezpośrednie odzwierciedlenie pierwotnych zachowań ludzkich (Thorpe 2005). Co więcej, nie wszystkie gatunki szympansów wykazują skłonność do agresji. Dobrym przykładem są np. szympansy Bonobo zachowujące się w sposób zdecydowanie odbiegający od schematu przytoczonego przez badaczy (De Waal 1989). Można zatem uznać, że odgórne przypisanie wspomnianemu gatunkowi małp naczelnych pewnych zestandaryzowanych wzorców zachowań nieuwzględniających różnic wewnątrzgatunkowych stanowi znaczne uproszczenie. Model R. Wranghama i D. Petersona dość luźno koresponduje również z przywołanym przez nich argumentem ,etnograficznym” - plemię Yanomamo nie ma w zwyczaju patrolować granic zajmowanego terytorium, uczestnikami poty- 
czek są najczęściej starsi, żonaci mężczyźni, a ofiarami tych starć niejednokrotnie padają najbliżsi krewni zamieszkujący okoliczne wioski (Chagnon 1996; Ferguson 2001).

\section{MODEL REPRODUKCYJNY}

Reprodukcyjna teoria warfare opiera się na założeniu, że występująca wśród młodych samców szympansów rywalizacja o dostęp do samic zachodzi również wśród ludzi i podobnie jak u prymatów może prowadzić do przemocy (Wrangham, Peterson 1996). Warto jednak zaznaczyć, że kilka niezależnych raportów etnograficznych, dotyczących wojujących społeczności przedpaństwowych, dowodzi, iż przemoc nie jest gwarantem sukcesu reprodukcyjnego (Kelly 2000, s. 20-35; Knauft 1987). Jednym z najsłynniejszych studiów poświęconych związkowi między agresywnością a sukcesem reprodukcyjnym jest praca Napoleona Chagnona poświęcona ludowi Yanomamo (Chagnon 1988), w której podkreśla on, że wojownicy mogący się poszczycić największą liczbą potwierdzonych zabójstw postrzegani byli jako szczególnie atrakcyjni i cieszyli się znacznym zainteresowaniem płci przeciwnej. $Z$ drugiej jednak strony N. Chagnon podaje, że w trakcie wypraw odwetowych wojownicy strony poszkodowanej zawsze wyruszali z nadzieją na wyeliminowanie osoby bezpośrednio odpowiedzialnej za zabójstwo ich krewnego (Chagnon 1988, s. 985). Innym etnografom udało się natomiast udokumentować niezwykle interesujące zjawisko. Ofiarami wypraw wojennych często byli również seryjni zabójcy, którzy w chwili śmierci wciąż pozostawali w wieku reprodukcyjnym (Albert 1990). Stąd przypuszczenie, że ponura sława skutecznego zabójcy niekoniecznie musiała zapewniać zainteresowanemu sukces reprodukcyjny.

Zbliżone, aczkolwiek nieco bardziej rozbudowane podejście do problemu zorganizowanej przemocy przedstawia wojnę jako nieunikniony skutek brutalnej rywalizacji młodych mężczyzn o prestiż społeczny (Maschner, Reedy-Maschner 1998). Podkreśla się przy tym, że w omawianym przypadku agresja i przemoc kanalizowane są na zewnątrz grupy. O słuszności takiej hipotezy po raz kolejny miałby świadczyć przykład Yanomamo (Maschner, Reedy-Maschner 1998). Jednak wobec faktu, że większość zabójców to mężczyźni między 25. a 40. rokiem życia, należy podać w wątpliwość zasadność powyższej argumentacji (Ferguson 2001, s. 109). Hipotezę tę dodatkowo osłabiają znaleziska archeologiczne, m.in. osławione cmentarzysko w Jebel Sahaba, stan. 117, na którym odkryto kilkadziesiąt szkieletów noszących ślady śmiertelnych uszkodzeń powstałych wskutek przemocy zadanej przez osoby trzecie. Co ciekawe, nieco mniej niż połowę pochówków uznano za kobiece.

Podstawową słabością wszystkich trzech teorii wywodzących się z nurtu socjobiologicznego/psychologiczno-ewolucyjnego jest to, że wojownicy współcześnie żyjących ludów łowiecko-zbierackich nierzadko przystępują do walki dopiero po 
osiągnięciu odmienionego stanu świadomości (Ehrenreich 1997; Kennedy 1971). W ramach przygotowań do wyprawy wojennej mężczyźni są często poddawani skomplikowanym rytuałom, w trakcie których nierzadko zażywają środki psychoaktywne. Taniec wojenny, opętanie przez duchy, publiczne przysięgi - wszystkie te zabiegi mają na celu przygotować wojownika na spotkanie z wrogiem, ściślej zaś: uczynić go zdolnym do odebrania życia innemu człowiekowi (Ehrenreich 1997; Kennedy 1971). Dzisiejsze media konsekwentnie karmią społeczeństwo obrazami nieustraszonych filmowych herosów mordujących rzesze wrogów bez mrugnięcia okiem i nawet cienia refleksji nad losem przedstawiciela tego samego gatunku. Obecnie przeświadczenie o łatwości zabicia człowieka umacniają również gry komputerowe, w których przemoc wręcz wylewa się z ekranu, a mord to często kwestia zaledwie jednego kliknięcia. Warto jednak zaznaczyć, że w rzeczywistości sprawa przedstawia się zgoła odmiennie. Według Dave'a Grossmana, autora znakomitego studium zabijania pt. On Killing, żołnierze historycznych pól bitewnych wcale nie palili się do odbierania życia swoim adwersarzom (Grossman 1996). Dane podane przez autora z początku mogą zdumiewać - otóż zaledwie 15-20\% żołnierzy walczących na frontach drugiej wojny światowej zdecydowało się otworzyć ogień w kierunku przeciwnika z intencją zranienia lub zabicia go. Autor książki, żołnierz zawodowy oraz wykształcony psycholog, wysunął hipotezę, wedle której zaledwie $2 \%$ żołnierzy biorących udział w działaniach wojennych to urodzeni wojownicy, a więc ludzie zdolni bez wahania odebrać życie drugiemu człowiekowi (Grossman 1996). Kolejna ciekawa uwaga dotyczy związku między rodzajem broni a oporem przed zabiciem przeciwnika. Otóż opór ten maleje wraz ze wzrostem odległości dzielącej potencjalnego mordercę od jego celu. Zdecydowanie najtrudniej zabić człowieka $\mathrm{w}$ walce $\mathrm{w}$ zwarciu, $\mathrm{z}$ użyciem broni białej. O wiele łatwiej wyeliminować wroga za pomocą broni dystansowej - z odległości nie dostrzega się bowiem większości szczegółów anatomicznych, często podświadomie uznawanych za atrybuty człowieczeństwa. Wobec powyższych danych zupełnie nie dziwi fakt, że wojownicy społeczności łowiecko-zbierackich, dysponujący przecież relatywnie prymitywnym uzbrojeniem, wedle przekazów etnograficznych często sięgali po środki zmieniające świadomość - pod ich wpływem łatwiej było odmówić przeciwnikowi człowieczeństwa, a tym samym uniknąć traumy dręczącej morderców po odebraniu życia ludzkiej istocie.

Wedle wszelkich dostępnych przesłanek zabijanie trudno uznać za czynność przychodzącą człowiekowi z łatwością. Teoria uznająca przemoc za naturalne, wręcz biologiczne następstwo pewnych praktyk społecznych wydaje się zatem mało prawdopodobna. Często sam udział w akcie przemocy, mogący potencjalnie zakończyć się odebraniem życia drugiemu człowiekowi, wymaga od napastników zastosowania środków prowadzących do zmiany stanu świadomości. Celem tych zabiegów jest najprawdopodobniej osłabienie oporu przed zabiciem przedstawiciela swojego gatunku. Skłonność do przemocy, przynajmniej tej potencjalnie skutkującej 
śmiercią ofiary, nie jest zatem cechą biologiczną. W tym miejscu warto również powołać się na nowogwinejskie plemię Sambia, praktykujące znamienny dla tego wywodu zwyczaj szkolenia przyszłych wojowników - młodzi chłopcy muszą porzucić rodzinę, by dalszy ciąg swojego życia spędzić w gronie dorosłych mężczyzn i nauczyć się rzemiosła wojennego (Herdt 1987). Konkludując: to kultura ludzka, a nie biologia, odpowiada za wykształcenie się u ludzi skłonności do przemocy. Jak pisał Bronisław Malinowski (Malinowski 1941, s. 23): „human beings fight not because they are biologically impelled but because they are culturally induced" [istoty ludzkie walczą nie dlatego, że są do tego biologicznie zobligowane, lecz wskutek określonych mechanizmów kulturowych, którym podlegają - tłum. R. S.].

Wracając jeszcze do EEA, warto wspomnieć, że model ten nie spotkał się $\mathrm{z}$ aprobatą archeologów. Nie byli oni skłonni zaakceptować założenia o stabilnym charakterze środowiska adaptacyjnego, w którym miał rozwijać się człowiek pierwsze istotne zmiany miałaby przynieść dopiero rewolucja neolityczna. Materiały archeologiczne stanowią jednak bezpośredni dowód na to, że kultura ludzka doby mezolitu, a nawet paleolitu wykazywała znaczne zróżnicowanie. Dlatego trudno trwać w przeświadczeniu, że wzorce zorganizowanej przemocy czy ogólniej rzecz biorąc charakter ówczesnych konfliktów nie podlegały, podobnie jak samo Środowisko Ewolucji Adaptacyjnej, dynamicznym zmianom.

\section{PODEJŚCIE MATERIALISTYCZNE}

Zwolennicy podejścia materialistycznego dążą do konceptualizacji problemu genezy zjawiska zorganizowanej przemocy w sposób diametralnie różny od przedstawicieli nurtu wywodzącego się z psychologii ewolucyjnej. Dystansują się oni od perspektywy biologicznej, przypisując wojnie bardziej ekonomiczny charakter. Uznają bowiem, że konflikt zbrojny to przedsięwzięcie na tyle ryzykowne, iż jedynie niedobór podstawowych surowców dla istnienia populacji zasiedlających dany obszar stanowi jego racjonalne uzasadnienie. Do surowców tych R. Ferguson zalicza np. terytorium oraz pożywienie (Ferguson 1990). Ten sam autor twierdzi również, że ideologiczna legitymizacja działań wojennych maskuje prawdziwe, czysto pragmatyczne motywy uczestników konfliktu. Poglądy R. Fergusona zostały szczególnie perswazyjnie wyeksplikowane w jego krytyce pracy innego badacza konfliktów zbrojnych, Azara Gata, przedstawiciela podejścia ekologiczno-ewolucyjnego (Ferguson 2000). Podstawowym założeniem wzmiankowanego nurtu jest przeświadczenie, według którego ludzkie zachowanie w ramach procesu ewolucji zostało tak zaprojektowane, by zmaksymalizować sukces reprodukcyjny przy jednoczesnym zaspokojeniu niezbędnych potrzeb materialnych. Wracając do krytyki wyrażonej przez R. Fergusona, podając w wątpliwość przekonanie o bardzo wczesnej metryce 
zorganizowanej przemocy, sięgającej zdaniem A. Gata czasów łowiecko-zbierackich, autor powołuje się m.in. na stanowisko 117 z Jebel Sahaba (Ferguson 2000, s.159). Datowane na 12 000-10 000 BC cmentarzysko uważane jest za najwcześniejsze świadectwo konfliktów zbrojnych; spośród 59 szkieletów 24 zaklasyfikowano jako należące do osób zabitych najprawdopodobniej z użyciem broni miotanej (Wendorf 1968, s. 90-93; Wendorf, Schild 1986, s. 818-824). Odwołując się do materialistycznego podejścia do problematyki wojny, R. Ferguson w pewnym stopniu bagatelizuje wczesne datowanie stanowiska i zwraca uwagę na jego zdaniem daleko bardziej istotny fakt. Pomimo że chronologicznie okres funkcjonowania cmentarzyska przypada na schyłek paleolitu, to korzystająca z niego ludność eksperymentowała już ze zbieractwem dziko rosnących zbóż kilka tysięcy lat przed wprowadzeniem gospodarki wytwarzającej. Kres temu eksperymentowi położyło nagłe pogorszenie warunków klimatycznych, co z kolei przełożyło się na wzrost napięcia w regionie. Napięcie to znalazło ujście w akcie zorganizowanej przemocy, którego ofiarą padły osoby pochowane na cmentarzysku w Jebel Sahaba (Hoffman 1993, s. 86-90). R. Ferguson ustosunkował się również do często przywoływanego przez A. Gata przykładu z terytorium północnej Australii, gdzie natrafiono na malowidła naskalne datowane na 8000-4000 BC, obrazujące szereg starć między zorganizowanymi grupami wojowników (Tacon, Chippindale 1994). Po raz kolejny zwrócił uwagę na zbieżność czasu powstania malowideł z nastaniem kryzysu ekologicznego, w trakcie którego doszło do podniesienia się poziomu morza i podtopienia żyznych nizin łączących niegdyś Australię z Nową Gwineą. Daleko posunięta instytucjonalizacja wojny na obszarze północnej Australii wynika, zdaniem autora, z koncentracji efemerycznych zasobów środowiska, np. studni lub tymczasowych źródeł, na niewielkim obszarze zasiedlanym przez rozrastającą się populację (Ferguson 2000, s. 159; Meggit 1962, s. 24, 42). Po raz kolejny zatem akcentuje się przyczynę środowiskową o charakterze ekonomicznym - podłożem konfliktu był najprawdopodobniej spór o dostęp do okresowych źródeł wody. Promowana przez A. Gata hipoteza o relatywnie wczesnej genezie konfliktów zbrojnych nie znajduje zdaniem Fergusona uzasadnienia w źródłach archeologicznych. Twierdzi on, że pierwsze wiarygodne świadectwa działań wojennych generowały populacje o bardziej osiadłym trybie życia i relatywnie wysokim stopniu komplikacji struktur społecznych, dodatkowo borykające się kryzysami środowiskowymi.

Do podobnych wniosków doszedł Jonathan Haas (1998). Według niego pierwsze materialne świadectwa zorganizowanej przemocy, być może nawet konfliktów zbrojnych, pochodzą już sprzed $20000-30000$ BC (Haas 1998, s. 6). Są to przede wszystkim szkielety ze śladami uszkodzeń w postaci ubytków kostnych oraz, aczkolwiek zdecydowanie rzadziej, grotów krzemiennych tkwiących w kościach. Niemniej jednak są to przypadki nieliczne i odosobnione, niewpisujące się w żaden wyraźny wzorzec chrono- i chorologiczny. Zdecydowanie liczniejszy materiał pochodzi 
z czasów poprzedzających upowszechnienie zdobyczy gospodarki wytwarzającej. Konstatacja ta dotyczy zarówno obszarów Starego Kontynentu, jak i obu Ameryk (Haas 1998, s. 7). Zdaniem J. Haasa czynnikiem odpowiedzialnym za eskalację konfliktów zbrojnych w czasach poprzedzających pierwszą rewolucję neolityczną była zwiększona stabilizacja osadnictwa. Powołuje się on m.in. na osławione stanowisko 117 z Jebel Sahaba (Wendorf 1968; Wendorf, Schild 1986). Cmentarzysko odkryte w jego obrębie stanowi materialny przejaw wzrostu identyfikacji z zasiedlanym terytorium, zwłaszcza że jak dotąd nie natrafiono tam na ślady żadnego stabilnego osiedla. Podobny wzorzec osadniczy rozpoznano w południowo-wschodniej części USA. Na szkielety ofiar konfliktów natrafiono w pobliżu śmietnisk muszlowych, świadczących o funkcjonowaniu relatywnie trwałych siedlisk ludzkich na terenach nadbrzeżnych (Millner 1997). Były to swoiste nisze ekologiczne obfitujące w łatwo dostępne, a przy tym kaloryczne pożywienie. Nietrudno sobie wyobrazić, że stanowiły one przedmiot sporu, który w okresach nieurodzaju z łatwością mógł się przerodzić w otwarty konflikt. Występowanie wyznaczników warfare na mezolitycznych stanowiskach reprezentujących relatywnie stabilne siedliska ludzkie wskazuje na znaczenie wzrostu zasiedziałości jako czynnika odpowiedzialnego za eskalację napięć międzygrupowych (Haas 1998, s. 8). Jednak aby mogło dojść do eskalacji konfliktu, musiały zaistnieć określone warunki demograficzne i środowiskowe, tj. postępujący wzrost liczebności populacji danego obszaru oraz jego degradacja ekologiczna. Pogląd ten w znacznym stopniu koresponduje z propozycją R. Fergusona i wyraźnie wpisuje się w nurt materialistyczny reprezentowany przez obu autorów.

Niemniej jednak również ta propozycja interpretacyjna, zdawałoby się racjonalna i wiarygodnie uzasadniona, ma swoje słabe strony. Studia etnograficzne poświęcone warfare wśród społeczności przedpaństwowych z obszaru Nowej Gwinei pokazują, że duża liczebność populacji nie zawsze staje się przyczyną eskalacji konfliktu. Warto w tym miejscu odnotować, że w najbardziej wojowniczych plemionach nowogwinejskich gęstość zaludnienia utrzymuje się na stosunkowo niskim poziomie (Knauft 1990). Z kolei w przypadku ludu Waorani z Ekwadoru częste konflikty zbrojne są następstwem nie tyle okresowych niedoborów podstawowych surowców dla przetrwania, ile raczej wynikają z kontekstu historycznego; z początku wojna przeciwko Inkom, a następnie działalność hiszpańskich konkwistadorów stworzyła solidne podłoże dla instytucjonalizacji przemocy (Robarchek, Robarchek 1998). Dla zobrazowania swojej hipotezy o stricte materialistycznym wymiarze działań wojennych R. Ferguson sięga, podobnie jak jego poprzednicy, po przykład plemienia Yanomamo (Ferguson 1995). Jego zdaniem walczą oni przede wszystkim o zapewnienie sobie trwałego dostępu do określonej kategorii dóbr materialnych, w tym przypadku siekier stalowych wykorzystywanych do karczowania terenów zalesionych. Co ciekawe, inni autorzy dalecy są od zaakceptowania takiej interpre- 
tacji (Peters 1998, s. 216). Ze względu na znaczną różnorodność wzorców przemocy nie można jednoznacznie stwierdzić, że warfare to w każdym wypadku przedsięwzięcie racjonalne, wynikające wyłącznie z pobudek materialnych. Nie przekonuje również koncepcja, według której powody wejścia na wojenną ścieżkę podawane przez samych zainteresowanych mają za zadanie maskować prawdziwy cel działań wojennych, mający zawsze, według zwolenników nurtu materialistycznego, podłoże pragmatyczne.

\section{EWOLUCJA KULTUROWA}

Na początki pierwszej dekady XXI w. przypada odrodzenie podejścia określanego mianem ewolucji kulturowej w badaniach nad genezą konfliktów zbrojnych (Dawson 2001), którego początki sięgają lat 60. wieku poprzedniego. Jego zwolennicy analizują zmiany zachodzące we wzorcach zorganizowanej przemocy w odniesieniu do przekształceń obserwowanych na płaszczyźnie społecznej i technologicznej. Często za moment kluczowy w historii warfare uznaje się upowszechnienie gospodarki wytwarzającej, aczkolwiek niektórzy badacze przyznają, że ewolucja działań wojennych $\mathrm{w}$ pradziejach mogła mieć charakter cykliczny. R. Mercer w swoim studium warfare dla obszaru Wielkiej Brytanii wskazał, że największe natężenie konfliktów zbrojnych datuje się na wczesny neolit. Natomiast wczesna epoka brązu przez wielu badaczy uważana za okres formowania się wojowniczych elit, dostarcza zaskakująco niewielu materialnych poświadczeń działań wojennych (Mercer 1999). Nasuwa się zatem pytanie, czy ówczesne elity społeczne, posiadające monopol na użycie przemocy, egzekwowały władzę w sposób niewymagający jej stosowania, czy też może w omawianym czasie nastąpiło wyraźne zmniejszenie intensywności działań wojennych?

Ostatnia z teoretycznych propozycji konceptualizacji warfare dystansuje się wobec próby unifikacji czynników generujących konflikty zbrojne. Zamiast podejścia generalizującego zwolennicy rzeczonej opcji interpretacyjnej postulują konieczność rozpatrywania każdego z analizowanych przypadków we właściwym mu kontekście historycznym oraz społeczno-ekonomicznym. Jest to rozwiązanie obiecujące poznawczo, gdyż ogromna różnorodność czynników odpowiedzialnych za wysoką częstość lub brak działań wojennych, zarysowana pokrótce w niniejszym tekście, wręcz stwarza konieczność przyjęcia perspektywy badawczej nieskrępowanej odgórnie przyjętymi założeniami teoretycznymi, wynikającymi z realizacji określonego paradygmatu badawczego. Przywołane podejście do problematyki zorganizowanej przemocy jest bardzo popularne wśród badaczy zajmujących się owym zagadnieniem, o czym świadczy wiele wartościowych publikacji, w których udało się je z powodzeniem zastosować. 


\section{GENEZA WARFARE A ARCHEOLOGIA. PRZEGLĄD NAJWCZEŚNIEJSZYCH ŚWIADECTW ZORGANIZOWANEJ PRZEMOCY}

\section{Paleolit dolny i środkowy}

Analiza materiałów archeologicznych pochodzących z epok poprzedzających wprowadzenie rozwiązań gospodarki wytwarzającej wskazuje, że pojedyncze przypadki przemocy interpersonalnej można z pewną dozą prawdopodobieństwa datować na środkowy, a niekiedy nawet na dolny paleolit. Są to jednak znaleziska jednostkowe, przede wszystkim szczątki kostne, które ze względu na swój wiek i zróżnicowany stan zachowania stanowią bardzo niepewną podstawę dla dalszych rozważań nad początkami konfliktów. Często bowiem niemożliwe jest jednoznaczne ustalenie okoliczności, w jakich powstało uszkodzenie tkanki kostnej - mogło być ono następstwem zarówno działalności procesów podepozycyjnych, jak i ingerencji padlinożerców. Wybór najwcześniej datowanych materiałów, stosunkowo często cytowanych w literaturze przedmiotu, zaprezentowano poniżej:

- Swanscombe (Anglia) - zaleczone uszkodzenia czaszki w postaci trzech wyraźnych wgłębień (Brothwell 1964);

- Ehringsdorf (Niemcy) - duży ubytek tkanki kostnej w rejonie kości czołowej (Keith 1931, s. 319);

- Fontéchevade (Francja) - otwór w kalocie czaszki (Vallois 1961);

- Sima de los Huesos, Atapuerca (Hiszpania) - 27 ludzkich szkieletów odnalezionych w jaskini, datowanych na ok. 350000 BC. Kilka czaszek nosi ślady zaleczonych uszkodzeń w postaci pęknięć i ubytków. Na czaszce nr 5 zarejestrowano aż 13 takich śladów (Fernández-Jalvo, Carlos Díez, Cáceres i Rosell 1999);

- Ngandong (Jawa) - zaleczone urazy czaszki rozpoznane na 5 spośród jedenastu odnalezionych czaszek. Cztery z 5 zaklasyfikowano jako kobiece (Coon 1962, s. 391)

Zdecydowanie więcej uszkodzeń kośćca potencjalnie świadczących o brutalnej ingerencji osób trzecich rozpoznano na szkieletach należących do neandertalczyków. T. Berger i E. Trinkaus (1995) poddali analizie szczątki kostne 200 osobników z obszaru Europy i Bliskiego Wschodu. Charakterystykę uszkodzeń przedstawiono $\mathrm{w}$ ujęciu komparatywnym - wyniki zestawiono bowiem z historycznymi raportami medycznymi ze szpitali w Nowym Jorku i Londynie, w których szczegółowo opisano przypadki urazów skutkujących licznymi złamaniami różnych partii kośćca. Zestawienie wykazało, że populację neandertalską charakteryzuje zwiększony udział uszkodzeń okolic głowy/szyi i korpusu. T. Berger i E. Trinkaus przyznali, że jedną z przyczyn opisanego stanu rzeczy mogła być przemoc interpersonalna, aczkolwiek badacze opowiadają się raczej za odmienną interpretacją tego zjawiska. Zauważono bowiem, że charakter urazów do złudzenia przypomina strukturę traumata właściwą współczesnym zawodnikom rodeo (Berger, Trinkaus 1995). 
Niemniej jednak odmienna hipoteza o genezie uszkodzeń również ma swoich zwolenników. J.C. Gardner, powołując się przy tym na znalezisko zdekompletowanego szkieletu z jaskini Krapina w Chorwacji, uważa, że koncepcja powstania zmian kostnych wskutek uczestnictwa w konflikcie jest dość prawdopodobna (Gardner 2001). Warto również dodać, że raport T. Bergera i E. Trinkausa uwzględnił jedynie te osobniki, których rany były na tyle poważne, by pozostawić ślady na kościach. Pomimo to procent poważnie rannych osobników nadal jest bardzo wysoki - wynosi bowiem aż 10\% (przy liczebności próby 200). Odnośnie do dokumentów medycznych wykorzystanych przez badaczy - pacjenci ze szpitala w Nowym Jorku zgłaszali się przeważnie $\mathrm{z}$ urazami ramion lub dłoni, powstałymi wskutek nieszczęśliwego upadku. Natomiast populacja londyńska składała się przede wszystkim $\mathrm{z}$ ofiar napaści, w związku z czym u poszkodowanych stwierdzono obrażenia zupełnie innego typu. Najczęściej uszkodzone były okolice głowy/szyi, przy wyraźnie mniejszym udziale innych części ciała. Istnieje zatem prawdopodobieństwo, że urazy głowy wśród populacji neandertalskiej również są wynikiem brutalnej napaści (McCall, Shields 2008). Co więcej, podobny typ traumata rozpoznano na szczątkach wczesnych homo sapiens z terenów Afryki i Bliskiego Wschodu, w związku z czym można przyjąć, że przemoc interpersonalna nie była wyłącznie udziałem neandertalczyków. Idąc dalej, płeć udało się określić jedynie u 5 osobników. Cztery szkielety określono jako należące do mężczyzn. Jest to bardzo nieliczna próba, niemniej jednak w pewnym stopniu wspiera ona hipotezę o przeważającym udziale osobników płci męskiej w aktach zorganizowanej przemocy (McCall, Shields 2008). Oprócz analiz kostnych, przeprowadzonych przez T. Bergera i E. Trinkausa, w piśmiennictwie naukowym opisano również dwa przypadki, w których uszkodzenia kośćca najprawdopodobniej powstały wskutek użycia broni. Komputerowa rekonstrukcja szkieletu z St. Cesaire, przeprowadzona przez C. Zollikofera (2001) i jego zespół, wykazała wyraźne, zagojone uszkodzenie czaszki, będące następstwem rany kłutej. W ramach oględzin szkieletu ze stanowiska Shanidar 3 stwierdzono ślad rany kłutej $\mathrm{w}$ rejonie klatki piersiowej, której materialnym świadectwem miał być ubytek tkanki kostnej w okolicy dziewiątego lewego żebra (Trinkaus 1983). W przeciwieństwie do przypadku z St. Cesaire nie odnotowano żadnych śladów gojenia, w związku z czym uznano, że cios najprawdopodobniej był śmiertelny. Ponadto kontekst znaleziska wskazuje, że broń tkwiła w ciele osobnika jeszcze długo po jego śmierci. Płeć obu pochówków określono jako męską.

\section{Paleolit górny/schyłkowy}

Górny paleolit dostarcza zdecydowanie więcej materialnych świadectw przemocy niż epoki poprzedzające. W omawianym okresie obrządek pogrzebowy „wychodzi” poza jaskinie, co ogranicza zestaw czynników wpływających na liczebność puli oraz stopień zachowania kości (Thorpe 2005). Ponadto górny paleolit to także 
przedstawienia aktów przemocy uwiecznione w postaci malowideł naskalnych oraz pierwsze znaleziska „broni”. I.J.N. Thorpe przypuszcza, że do wynalezienia łuku doszło na obszarze Starego Świata po 20000 BC, aczkolwiek przyznaje, iż jak dotąd nie natrafiono na pewne znaleziska mogące potwierdzić słuszność jego hipotezy (Thorpe 2003). Przywołuje jednak siedem naskalnych przedstawień istot antropomorficznych ugodzonych strzałami bądź oszczepami (Guilaine, Zammit 2005, s. 85-89). Mogą one rzeczywiście przedstawiać zabójstwa, jak również stanowić przejaw skomplikowanych praktyk magicznych (Lewis-Williams 2002, s. 277-281).

Z obszaru Włoch pochodzą znaleziska dwóch szkieletów z krzemiennymi ostrzami tkwiącymi w kościach (Bachechi, Fabbri, Mallegni 1997). Pierwszy odnaleziono w miejscowości San Teodoro na Sycylii. Został on zaklasyfikowany jako żeński, fragment ostrza tkwił w kości miednicy. Drugi odkryto w Grimaldi, w regionie Kalabria. Był to szkielet dziecka. Ostrze tkwiło w kościach kręgosłupa (Henry-Gambier 2001). Nie udało się jednoznacznie ustalić, czy ostrza osadzone były na drzewcach włóczni, czy też może stanowiły zwieńczenie strzał.

Niezwykłych znalezisk rzucających nowe światło na problem genezy warfare dostarczyła sudańska nekropola, znana szerzej jako „site 117” (Wendorf 1968). Znajduje się ona na północnym brzegu Nilu, mniej więcej w połowie drogi między Wadi Halfa i Jebel Sahaba. Stanowisko było badane w latach 1965-1966 przez członków ekspedycji amerykańsko-fińskiej pod kierownictwem Freda Wendorfa. Jedna data C14 dała rezultat $13500 \mathrm{BC}$, co pozwoliło badaczom uznać nekropolę za epipaleolityczną i powiązać ją z tradycją kultury Quadan. Jest to pierwsze w pełni wiarygodne świadectwo pradziejowego konfliktu zbrojnego. Spośród 59 odsłoniętych pochówków aż w 24 zarejestrowano krzemienne groty strzał tkwiące w kościach lub zalegające w obrębie klatki piersiowej. Ogółem pozyskano 110 grocików. Zdaniem F. Wendorfa niemal wszystkie odsłonięto w pozycji wskazującej, że przebiły one ciała zmarłych jako groty strzał lub oszczepów. Ofiarami przemocy byli mężczyźni, kobiety oraz dzieci, aczkolwiek więcej śladów uszkodzeń znaleziono na szkieletach męskich. Przyczyny masakry nie są do końca jasne. Fred Wendorf, podobnie jak R. Ferguson, wskazuje na presję środowiskową (Wendorf 1968). I.J.N. Thorpe dodaje, że nekropola z Jebel Sahaba mogła stanowić miejsce grzebalne dla tych, którzy stracili życie wskutek ,złej śmierci” - innymi słowy: zostali zamordowani (Thorpe 2003). Bardzo wysoki procent pochówków noszących wyraźne ślady przemocy stanowi wyjątkowy przypadek i nie znajduje analogii w materiałach $\mathrm{z}$ górnego/schyłkowego paleolitu.

\section{Mezolit}

Badanie problemu zorganizowanej przemocy w odniesieniu do mezolitu wiąże się z koniecznością rozpatrywania omawianego zjawiska w skali lokalnej. Wykazuje ono bowiem tak daleko idące zróżnicowanie regionalne, że nie sposób na podstawie 
wszystkich zebranych obserwacji uzyskać generalny, spójny model wyjaśniający przyczynę, przebieg i charakter konfliktów w analizowanym okresie dziejów.

Zdaniem niektórych badaczy (Vencl 1984; Thorpe 2003) w mezolicie doszło do ukształtowania się pierwocin zorganizowanej przemocy wpisującej się w definicję warfare, a więc ,zorganizowanego działania grupy ludzi związanego z użyciem fizycznej przemocy, skierowanego w inną grupę ludzi sformowaną (lub nie) w tym samym celu" (Ferguson 1984). Według S. Vencla czynnikiem inicjującym zmiany na płaszczyźnie społecznej było przede wszystkim wyraźne ocieplenie klimatu, które nastąpiło wraz z nadejściem holocenu. Stosunkowo wysoka średnia roczna temperatura i wilgotność stwarzały warunki sprzyjające rozwojowi obszarów leśnych, zamieszkiwanych przez raczej osiadłe gatunki zwierząt, co zwalniało ówczesnych łowców z konieczności uczestniczenia w okresowych wędrówkach za stadami. W krótkim czasie nastąpił znaczny wzrost ilości i różnorodności dostępnego pożywienia. Egzystujące w tym środowisku populacje stopniowo przechodziły na bardziej osiadły tryb życia i konsekwentnie eksploatowały zasiedlane obszary. Ułatwiony dostęp do pokarmu i łagodny klimat przyczyniły się do wzrostu liczebności populacji. Istnienie zajmowanych przez grupy ludzkie terytoriów zaowocowało nadaniem im określonych granic. Wysoki przyrost naturalny, zwiększająca się gęstość zaludnienia oraz niewielka mobilność zainicjowały proces postępującej dyferencjacji kulturowej. Próby przejęcia kontroli nad zasiedlanymi przez innych łowcówzbieraczy strefami eksploatacji stanowiły zapewne zarzewie lokalnych konfliktów, a w najbardziej ekstremalnych przypadkach mogły prowadzić do eksterminacji jednej z rywalizujących ze sobą grup. Hipoteza ta ma thumaczyć odkrycie szkieletów noszących ślady śmiertelnych ran, należących nie tylko do mężczyzn, ale również do kobiet i dzieci, na datowanych na okres mezolitu europejskich i północnoafrykańskich cmentarzyskach (Vencl 1984, s. 12).

Niemniej jednak, o czym nadmieniono we wstępie do tego podrozdziału, liczba archeologicznych świadectw konfliktów zbrojnych zdecydowanie różni się w zależności od analizowanego obszaru. W zachodniej części strefy śródziemnomorskiej natrafiono dotąd na co najmniej 400 pochówków datowanych na mezolit, z czego większość odkryto w obrębie śmietnisk muszlowych (Cunha, Cardoso, Umbelino 2003; Lubell, Jackes, Meiklejohn 1989). Na portugalskim stanowisku Moita do Sebastião odnaleziono szkielet z raną kłutą stopy, powstałą najprawdopodobniej wskutek trafienia pociskiem. Pękniętą kość ramienia oraz ubytek na kości czaszki rozpoznano na pochówku z Cabeço da Arruda. Są to jedyne stosunkowo pewne świadectwa napaści z tego obszaru poza kilkoma przypadkami tzw. parry fractures, których związek z aktami przemocy interpersonalnej został niedawno podany w wątpliwość (Lovell 1997). Można więc zaryzykować stwierdzenie, że europejska część basenu Morza Śródziemnego (gdyż sytuacja w rejonie Grecji i Włoch prezentuje się podobnie) wraz z południowym odcinkiem wybrzeża atlantyckiego była w mezolicie obszarem wolnym od konfliktów zbrojnych. 
Z obszaru Ukrainy pochodzi kilka przypadków najprawdopodobniej śmiertelnych ran po pociskach, które pozostawiły ślady na kościach (Alekšin 1994; Cordier 1990; Lillie 2001; Vencl 1991, 1999). Dwa takie pochówki odkryto na cmentarzysku w miejscowości Volos'ke, jeden zaś na nekropoli w Vasylivce, stan. 1. Na stanowisku Vasylivka 3 natrafiono na dwa pochówki z ranami po strzałach: jeden z kościanym grotem tkwiącym między kręgami oraz kilka strzaskanych czaszek. Przypuszcza się, że wzmiankowane cmentarzyska pełniły funkcję markerów terenowych, reprezentujących prawo danej społeczności do wyłącznego korzystania z okolicznych terytoriów łowieckich (Lillie 2001, s. 56). Jest wysoce prawdopodobne, że w określonych warunkach demograficzno-środowiskowych owe mateczniki zwierzyny łownej mogły stać się powodem brutalnego konfliktu.

Z obszaru Europy Środkowej pochodzi najstarsze wiarygodne znalezisko łuku. $\mathrm{Na}$ jego pozostałości natknięto się na stanowisku w miejscowości Stelmoor w Niemczech. Znaleziony egzemplarz wydatowano na 8500 BC (Guilaine, Zammit 2001, s. 97-103). Wprowadzenie łuku nie tylko wpłynęło na rozwój stosowanych wówczas technik łowieckich. Stworzyło również nowe sposoby rozwiązywania konfliktów wewnątrz- i międzygrupowych. Wybrane materiały kostne z obszaru Niemiec korespondują $\mathrm{z}$ tą koncepcją, czego najlepszym przykładem jest znalezisko z jaskini Offnet w Bawarii (Frayer 1997). W granicach stanowiska zarejestrowano dwie jamy, w których znaleziono łącznie 38 czaszek ludzkich pokrytych warstwą ochry. Jedynie 4 były męskie. Spośród pozostałych 9 uznano za żeńskie, 20 określono jako dziecięce. Co najmniej połowa osobników została przed śmiercią uderzona w głowę tępym narzędziem. Najwięcej uszkodzeń zidentyfikowano na czaszkach męskich (do siedmiu pęknięć). Na kilku czaszkach rozpoznano ślady cięcia, jednak zdaniem badaczy nie były one związane z aktami kanibalizmu czy ekstrakcją mózgu. Na podobne znaleziska natrafiono w miejscowościach Kaufertsberg i Hohlenstein, aczkolwiek liczba czaszek była zdecydowanie mniejsza (Orschiedt 1998). Na podstawie wielkości depozytu z Offnet można przypuszczać, że wymordowano niewielką społeczność. W omawianym przypadku niejasny kontekst oraz brak dodatkowych informacji uniemożliwiają ustalenie przyczyny zajścia, przez co rzeczonemu znalezisku często przypisuje się znaczenie rytualne.

$\mathrm{W}$ trakcie eksploracji mezolitycznych śmietnisk muszlowych z miejscowości Teviec i Hoedic natrafiono na pochówki mężczyzn, kobiet i dzieci (Péquart 1954). Na pierwszym stanowisku odsłonięto łącznie 23 szkielety, na drugim zaś 14. Ekspertyza wykazała obecność kilku zaleczonych pęknięć na kościach przedramion i na obojczykach; w Teviec odkryto ponadto dwa pochówki dorosłych osób, prawdopodobnie oba męskie. W kręgach pierwszego z nich tkwiły dwa groty krzemienne. Kości twarzoczaszki drugiego nosiły ślady licznych uszkodzeń.

Znaczna liczba szkieletów z traumata pochodzi z obszaru Skandynawii. Kościane groty strzał znaleziono pośród kości klatki piersiowej pochówków z cmentarzysk mezolitycznych w miejscowościach Backasog (dorosła kobieta) i Stora Bjars (dorosły 
mężczyzna) (Albrethsen, Brinch Petersen 1976). Nekropola w Skateholm 1 dostarczyła kilku spektakularnych znalezisk w postaci traumata: jeden $\mathrm{z}$ pochowanych mężczyzn ucierpiał od strzały, której grot utkwił w kości miednicy; dodatkowo rozpoznano u niego złamania kości kończyn górnych i dolnych (Larsson 1989). W przypadku kolejnego pochówku męskiego przyczyną śmierci była najprawdopodobniej rana od strzały, której kościany grot znaleziono między kośćmi. Kolejne trzy osobniki doznały urazów czaszki, jednak ślady gojenia wskazują, że nie były to rany śmiertelne. Na stanowisku w Tagerup odsłonięto szkielet dziesięcioletniego dziecka zranionego w biodro - materialnym świadectwem jego cierpienia był fragment grotu strzały wciąż tkwiący w kości w momencie dokonania odkrycia. W grobie masowym z miejscowości Vedbaek (Dania) odkryto szczątki trzech osób. U jednej z nich stwierdzono obecność kościanego grotu strzały w okolicach gardła. Badacze są zdania, że zmarli zostali złożeni do grobu w trakcie jednorazowego aktu, w związku z czym dopuszcza się hipotezę o ich nagłej i gwałtownej śmierci (Albrethsen, Brinch Petersen 1976). Ekspertyza materiałów kostnych przeprowadzona przez Pię Bennicke (Bennicke 1985, s. 98-101) wykazała znaczny udział uszkodzeń głowy w typie pęknięć i zagłębień oraz stosunkowo niewielką liczbę urazów innych części ciała. Obserwacja ta koresponduje ze wzmiankowanym wcześniej przeświadczeniem o braku wyraźnego związku obrażeń kości czaszki z tzw. parry fractures, z którymi przez pewien czas je wiązano. Większość szkieletów ze śladami uszkodzeń sklasyfikowano jako męskie. Według A. Fischera (2002, s. 372) struktura niemal połowy pęknięć i zagłębień rozpoznanych na czaszkach męskich wskazuje, że cios zadano toporem kamiennym lub podobnym narzędziem (Fischer 2002, s. 372). Omówienie materiałów skandynawskich zamyka pochówek dziesięcioletniego dziecka z cmentarzyska w Dyrholmen (Jutlandia); na jego czaszce rozpoznano ślady cięcia łudząco podobne do ubytków kostnych powstających w wyniku skalpowania (Anger, Dieck 1978, s. 166-167).

Wyjątkowo interesująco przedstawiają się wzorce przemocy rozpoznane na stanowiskach mezolitycznych z obszaru Żelaznych Wrót. Cztery naddunajskie stanowiska - Lepenski Vir, Vlasac, Padina, Hajdučka - datowane na okres od 7000 do 5500 BC, dostarczyły łącznie 263 szkieletów, które poddano szczegółowym oględzinom ukierunkowanym na rozpoznanie wszelkich śladów po urazach (Roksandič 2006). Badanie wykazało, że zaledwie w 6 przypadkach można $\mathrm{z}$ pewną dozą ostrożności wnioskować o powstaniu uszkodzeń w kontekście przemocy interpersonalnej. Jest to zatem wyjątkowo niski wynik, świadczący o relatywnie spokojnym trybie życia populacji mezolitycznych z prawego brzegu Dunaju. Mirjana Roksandič wykorzystała powyższe dane do weryfikacji dwóch wyjściowych hipotez badawczych: po pierwsze chciała sprawdzić, czy materiały z Żelaznych Wrót wspierają koncepcję o „hobbesowskim” (tj. apokaliptyczna wizja „wojny wszystkich przeciw wszystkim") charakterze konfliktów zbrojnych w mezolicie. Drugi z podjętych problemów badawczych dotyczył oceny wpływu penetracji pierwszych rolników na osadnictwo mezolityczne - w piśmiennictwie naukowym pojawiały się bowiem 
głosy o prawdopodobieństwie zaistnienia napięć na linii pierwsi rolnicy-łowcy-zbieracze, potencjalnie skutkujących wybuchem otwartego konfliktu (Roksandič 2006). Dowodem na słuszność pierwszej hipotezy byłaby znaczna liczba uszkodzeń kośćca u przedstawicieli obu płci i różnych kategorii wiekowych. Pozytywna weryfikacja drugiej byłaby możliwa w sytuacji, gdyby w puli materiałów kostnych, datowanych na okres od 6500 do 5000 BC (inicjalny etap akcji osadniczej pierwszych rolników w rejonie Żelaznych Wrót), stwierdzono zwiększony udział materiałów w typie traumata. Niewielki odsetek szkieletów ze śladami uszkodzeń kośćca uznano za argument wystarczający do podważenia słuszności obu koncepcji. Wobec powyższych danych sytuacja na lewym brzegu Dunaju, a więc w niewielkiej odległości od wzmiankowanych stanowisk, rysuje się w sposób zgoła nieoczekiwany.

Spośród 57 szkieletów odsłoniętych w trakcie dwóch kampanii wykopaliskowych na lewobrzeżnym, naddunajskim cmentarzysku w Schela Cladovei rozpoznano 5 z grotami strzał tkwiącymi w kościach i 14 reprezentujących inne rodzaje traumata. Łącznie daje to 19 szkieletów, co stanowi 33,3\% analizowanej próby. Współczynnik przemocy w rozpatrywanym przypadku jest zatem bardzo wysoki. Z kolei w Schela Cladovei stan. III natrafiono na szczątki 28 osobników, z czego u 7 zarejestrowano ślady uszkodzeń. Na dwóch czaszkach stwierdzono ubytki powstałe najprawdopodobniej wskutek uderzenia ciężkim narzędziem obuchowym; u dwojga zmarłych, mężczyzny i kobiety, rozpoznano pęknięcia kości przedramienia; w kolejnych trzech przypadkach za przyczynę śmierci uznano kościane i krzemienne groty strzał tkwiące w kościach. Analiza kości pod kątem diety wykazała, że wszystkie osobniki wpisują się $\mathrm{w}$ ten sam schemat żywieniowy - spożywali oni głównie pokarm pochodzenia „wodnego”. Zdaniem Mirjany Roksandic materiał z Schela Cladovei III reprezentuje zwarty horyzont czasowy, co dodatkowo potwierdza jednolity charakter obrządku pogrzebowego. Zarejestrowane uszkodzenia kośćców mogą reprezentować zarówno jednostkowy akt zorganizowanej przemocy, jak i serię powiązanych ze sobą wydarzeń (Roksandič 2006). Ofiarami agresji byli przedstawiciele obu płci, co koresponduje z kryterium substitability (zastępowalności), leżącego u podstaw definicji warfare autorstwa Raya Kelly'ego (2000). Epizodu „wojennego” z Schela Cladovei III nie można jednak, zdaniem Roksandic, wiązać z problemem kontaktu łowców-zbieraczy z pierwszymi rolnikami. Przeczą temu uzyskane daty C14, które zasadniczo nie wykraczają poza granicę ustaloną na $6500 \mathrm{BC}$. Ponadto dieta przebadanych osobników obfitowała w pokarm rzeczny, co potwierdza jej mezolityczny charakter.

\section{ZAKOŃCZENIE}

Podsumowując: przedstawione dane trudno przyporządkować jednej uogólnionej koncepcji teoretycznej dotyczącej genezy zorganizowanej przemocy w pradziejach. Z archeologicznego punktu widzenia konflikty zbrojne wybuchały wśród 
przedstawicieli społeczności preagrarnych zasiedlających wszystkie obszary Starego Kontynentu, aczkolwiek natężenie działań wojennych wykazywało znaczne zróżnicowanie w czasie i przestrzeni. Warto jednak zwrócić uwagę na to, że intensywność warfare, mierzona $\mathrm{w}$ tym przypadku liczbą znalezisk materiałów kostnych w typie traumata, wzrasta wyraźnie wraz z nadejściem holocenu. Wyraźne ocieplenie klimatu i łatwiejszy dostęp do pożywienia wywarły ogromny wpływ na organizację ówczesnych społeczeństw. Najprawdopodobniej zaistniałe warunki środowiskowe umożliwiły ludziom przejście na bardziej osiadły tryb życia. Zdaniem przywoływanego już J. Haasa ta inicjalna forma zasiedziałości, objawiająca się między innymi postępującą identyfikacją z zajmowanym terytorium (manifestowaną również na płaszczyźnie materialnej poprzez tworzenie cmentarzysk) stworzyła warunki dla eskalacji napięć społecznych, które w określonych okolicznościach mogły przerodzić się w otwarty konflikt zbrojny. Czy można sprecyzować, o jakie okoliczności chodzi? Przedstawiciele podejścia materialistycznego akcentują znaczenie zmian klimatyczno-środowiskowych, skutkujących zmniejszeniem się dostępnych zasobów wody i pożywienia oraz koncentrację tychże na niewielkim, stosunkowo gęsto zasiedlonym obszarze. Jest to jednak tylko jedna z interpretacji. Badania etnograficzne dostarczają danych, w świetle których nakreślone powyżej przyczyny konfliktów nie znajdują uzasadnienia. Problem genezy konfliktów, instytucjonalizacja przemocy czy wzorce działań wojennych to zagadnienia uwikłane w skomplikowaną sieć powiązań biologicznych, społecznych, ekonomicznych i ideologicznych, wobec czego wszelkie próby konstruowania uproszczonych modeli interpretacyjnych skazane są na niepowodzenie. Warto zatem wyjść poza ścisłe ramy przyjętego paradygmatu badawczego, by dotrzeć do sedna wydarzeń, które przecież stanowią materialny zapis całej gamy różnych emocji, jak choćby bólu, gniewu czy cierpienia, będących udziałem ludzi dających obecnie milczące świadectwo nagłej śmierci, którą archeolodzy niekiedy bezrefleksyjnie próbują skonceptualizować.

\section{BIBLIOGRAFIA}

Albert B.

1990 On Yanomami warfare: rejoinder. Current Anthropology, 31, s. 558-563.

Albrethsen S.E., Brinch Petersen E.

1976 Excavation of a Mesolithic cemetery at Vedbaek, Denmark. Acta Archaeologica, 47, 1-28. Alekšin V. A.

1994 Mesolithische Gräberfelder der Ukraine (chronologische, kulturelle und soziologische Aspekte der Interpretation). Zeitschrift fur Archaologie, 28, s. 163-189. Anger S., Dieck A.

1978 Skalpieren in Europa seit dem Neolithikum bis um 1767 nach Chr. Bonner Hefte zur Vorgeschichte, 17, s. 153-240. 
Bachechi L., Fabbri P.F., Mallegni F.

1997 An arrow-caused lesion in an Upper Palaeolithic human pelvis. Current Anthropology, 38, s. 134-140.

Bennicke P.

1985 Palaeopathology of Danish Skeletons. København: Akademisk Forlag.

Berger T.D., Trinkaus E.

1995 Patterns of trauma among the Neanderthals. Journal of Archaeological Science, 22, s. $841-852$.

Brothwell D.R.

1964 Further comments on the right parietal from Swanscombe: anomalies and endocranial features. W: C.D. Ovey (red.), The Swanscombe Skull: a survey of research on a Pleistocene site (s.173-174). London: Royal Anthropological Institute, Occasional Paper 20.

Buliński T., Kairski M.

2006 Sny, trofea, geny i zmarli. „Wojna” w spotecznościach przedpaństwowych na przykładzie Amazonii - przeglad koncepcji antropologicznych. Poznań: Wydawnictwo Naukowe UAM.

Chagnon N.

1988 Life histories, blood revenge and warfare in a tribal population. Science, 239, s. 985-992.

Chagnon N.

1996 Chronic problems in understanding tribal violence and warfare. W: G.R. Bock, J.A. Goode (red.), Genetics of Criminal and Antisocial Behavior (s. 202-236). New York: John Wiley.

Coon C.S.

1962 The Origins of Races. New York: Alfred A. Knopf.

Cordier G.

1990 Blessures préhistoriques animales et humaines avec armes ou projectiles conservés.

Bulletin de la Société Préhistorique Française, 87, s. 462-481.

Cunha E., Cardoso F., Umbelino C.

2003 Inferences about Mesolithic life style on the basis of anthropological data: the case of the Portuguese shell middens. W: L. Larsson, H. Kindgren, K. Knutsson, D. Loeffler, A. Åkerlund (red.), Mesolithic on the Move (s. 184-188). Oxbow: Oxford.

Dawson D.

2001 The First Armies. London: Cassel.

Ehrenreich B.

1997 Blood Rites. New York: Metropolitan Books.

Ferguson R.B. (red.)

1984 Warfare, Culture, and Environment. Orlando: Academic Press.

Ferguson R.B.

1990 Explaining War. W: J. Haas (red.), The Anthropology of War (s. 26-55). Cambridge: Cambridge University Press.

Ferguson R.B.

1995 Yanomami Warfare: a political history. Santa Fe NM: School of American Research Press.

Ferguson R.B.

2000 The Causes and Origins of "Primitive Warfare". On Evolved Motivations for War. Anthropological Quarterly, 73, s. 159-164.

Ferguson R.B.

2001 Materialist, cultural and biological theories on why Yanomami make war. Anthropological Theory, 1, s. 99-116. 
Fernández-Jalvo Y., Carlos Díez J., Cáceres I., Rosell J.

1999 Human cannibalism in the early Pleistocene of Europe. Journal of Human Evolution, 37, s. 591-622.

Fischer A.

2002 Food or feasting? An evaluation of explanations of the neolithisation of Denmark and southern Sweden. W: A. Fischer, K. Kristiansen (red.), The Neolithisation of Denmark: 150 years of debate (s. 343-393). Sheffield: J.R. Collins Publications..

Frayer D.W.

1997 Ofnet: evidence of a Mesolithic massacre. W: D.L. Martin, D.W. Frayer (red.), Troubled Times (s. 181-216). New York: Gordon and Breach.

Gardner J.C.

2001 An analysis of the pathology of Krapina Neanderthals. American Journal of Physical Anthropology, 35, s. 68 (abstract).

Grossman D.

1996 On Killing. The Psychological Cost of Learning to Kill in War and Society. BostonNew York-London: Back Bay Books.

Guilaine J., Zammit J.

2001 Le Sentier de la Guerre. Paris: Seuil.

Guilaine J., Zammit J.

2005 Origins of War. Violence in Prehistory. Blackwell Publishing.

Haas J.

1998 Warfare and the evolution of culture. Santa Fe: Santa Fe Institute.

Henry-Gambier D.

2001 La Sépulture des Enfants de Grimaldi. Paris: Réunion des Musées Nationaux.

Herdt G.

1987 The Sambia: ritual and gender in New Guinea. New York: Holt, Rinehart and Winston.

Hoffman M.

1993 Egypt before the pharaohs. New York: Alfred Knopf.

Keith A.

1931 New Discoveries Relating to the Antiquity of Man. London: Williams and Norgate.

Kelly R.C.

2000

Warless Societies and the Origin of War. Ann Arbor: University of Michigan Press.

Kennedy J.

1971 Ritual and intergroup murder: comments on war, primitive and modern. W: M.N. Walsh (red.), War and the Human Race (s. 40-61). Amsterdam: Elsevier.

Knauft B.M.

1987 Reconsidering violence in simple human societies: homicide among the Gebusi of New

Knauft B.M.

Guinea. Current Anthropology, 28, s. 457-500.

1990 Melanesian warfare: a theoretical history. Oceania, 60, s. 250-311.

Larsson L.

1989 Late Mesolithic settlements and cemeteries at Skateholm, southern Sweden. W: C. Bonsall (red.), The Mesolithic in Europe (s. 367-378). Edinburgh: John Donald.

Lewis-Williams D.

2002 The Mind in the Cave: consciousness and the origins of art. London: Thames and Hudson.

Lillie M.C.

2001 Mesolithic cultures of Ukraine. W: K.J. Fewster, M. Zvelebil (red.), Ethnoarchaeology and Hunter-Gatherers: pictures at an exhibition (BAR International Series, 955, s. 53-63). Oxford: Archaeopress. 
Lovell N.C.

1997 Trauma analysis in palaeo-pathology. Yearbook of Physical Anthropology, 40, s. $139-170$.

Lubell D., Jackes M., Meiklejohn C.

1989 Archaeology and human biology of the Mesolithic-Neolithic transition in southern Portugal: a preliminary report. W: C. Bonsall (red.), The Mesolithic in Europe. Edinburgh: John Donald.

Malinowski B.

1941 War - past, present and future. W: J.D. Clarkson, T.C. Cochran (red.), War as Social Institution. New York: AMS Press.

Maschner H.D.G, Reedy-Maschner K.L.

1998 Raid, retreat, defend (repeat): the archaeology and etnohistory of warfare in the Pacific rim. Journal of Anthropological Archaeology, 17, s. 19-51.

McCall G.S., Shields N.

2008 Examining the evidence from small-scale societies and early prehistory and implications for modern theories of aggression and violence. Aggression and Violent Behavior, 13, s. $1-9$.

Meggit M.J.

1962 Desert People. A study of the Walbiri aborigines of Central Australia. Chicago, Il: University of Chicago Press.

Mercer R.J.

1999 The origins of warfare in the British Isles. W: J. Carman, A. Harding (red.), Ancient Warfare. Archaeological Perspectives (s. 143-157). Stroud: Sutton Publishing.

Millner G.

1997 Prehistoric Warfare in Eastern America. Journal of Archaeological Research, 5.

Orschiedt J.

1998 Ergebnisse einer neuen Untersuchung der spätmesolithischen Kopfbestattungen aus Süddeutschland. W: N. Conrad (red.), Aktuelle Forschungen zum Mesolithikum (s. 147-160). Tübingen: Urgeschichtliche Materialhelfte 12.

Péquart M., Péquart S-J.

1954 Hoédic: deuxième station-nécropole mésolithique du Morbihan. Anvers: De Sikkel.

Peters J.F.

1998 Life among the Yanomami. Orchard Park NY: Broadview Press.

Pinker S.

$1998 \quad$ How the Mind Works. London: Penguin.

Ridley E.M.

2003 Nature Via Nurture: genes, experience, and what makes us human. London: Fourth Estate.

Robarchek C., Robarchek C.

1998 Waorani: the contexts of violence and war. Fort Worth: Harcourt Brace.

Roksandi M.

2006 Violence in the Mesolithic. Documenta Praehistorica, 33, s. 165-181.

Taçon P., Chippindale C.

1994 Australia's ancient warriors: changing depictions of fighting in the rock art of Arnhem Land, N.T. Cambridge Archaeological Journal, 4, s. 211-248.

Thorpe I.J.N.

2003 Anthropology, Archaeology and the origin of warfare. World Archaeology, 35, s. $145-165$. 
Thorpe I.J.N.

2005 The ancient origins of warfare and violence. W: M.P. Pearson, I.J.N Thorpe (red.), Warfare, violence and slavery in prehistory: proceedings of a Prehistoric Society conference at Sheffield University (BAR International Series, 1374, s. 1-18). Oxford: Archaeopress.

Trinkaus E.

1983 The Shanidar Neandethals. London: Academic Press.

Vallois H.V.

1961 The evidence of skeletons. W: S.L. Washburn (red.), Social Life of Early Man (s. 214-235). NY: Viking Fund Publications in Anthropology 31.

Vencl S.

1984 War and Warfare in Archaeology. Journal of Anthropological Archaeology, 3, s. $116-132$.

Vencl S.

1991 Interprétation des blessures causées par les armes au Mésolithique. L'Anthropologie, 95, s. 219-228.

Vencl S.

1999 Stone Age warfare. W: J. Carman, A. Harding (red.), Ancient Warfare: archaeological perspectives (s. 57-72). Stroud: Sutton.

De Waal F.B.M.

1989 Peacemaking among Primates. Cambridge MA: Harvard University Press.

Wendorf F.

1968 Site 117: a Nubian Final Palaeolithic graveyard near Jebel Sahaba, Sudan. W: F. Wendorf (red.), The Prehistory of Nubia (vol. 2, s. 954-1040). Dallas: Southern Methodist University Press.

Wendorf F., Schild R.

1986 The Wadi Kubbaniya Skeleton: a Late Palaeolithic burial from southern Egypt. Dallas: Southern Methodist University Press.

Wilson E.O.

1978 On Human Nature. Cambride MA: Harvard University Press.

Wrangham R.W., Peterson D.

1996 Demonic males: apes and the origins of human violence. London: Bloomsbury.

Zollikofer C.P.E., Ponce de León M.S., Vandermeersch B., Lévêque F.

2001 Evidence for interpersonal violence in St. Césaire Neanderthal. Proceedings of the National Academy of Sciences, 99, s. 6444-6448.

\section{PROBLEM OF ORGANISED VIOLENCE IN THE LIGHT OF ARCHAEOLOGICAL EVIDENCE}

\section{S u m mary}

The problem of origins of violence in prehistory still raises many controversies among scholars representing nearly all branches of social sciences. The large number of existing interpretations only complicates the current state of research. This paper's aim is to present and briefly discuss two main theoretical approaches to the problem. Both are derived from anthropology, although 
they do not have much in common. The first one, name it evolutionary, considers organized violence as an adaptive trait developed in humans over millions of years of their presence in the socalled "Environment of Evolutionary Adaptation" or as a set of patterns of social behavior inherited from humans' and chimpanzees' common ancestor. Followers of the second approach do not share this bio-evolutionary rhetoric. The materialist school claims that escalation of violent encounters in prehistory was a specific sort of by-product of an human adaptation to Holocene's climatic conditions. Competition for limited material resources, such as water and food, additionally induced with significant population growth and unstable climatic and environmental conditions founded a strong basis for first disturbances, which eventually developed into small-scale warfare. Both conceptions, as was stated above, are of anthropological origin. Therefore the article's second goal is to compare two main theoretical approaches to warfare with archaeological evidence representing the earliest known cases of interpersonal organized violence, perpetrated on a definitely larger scale. Its incorporation creates new research possibilities - archaeological record, in contrast to some ethnographic data, is not distorted by the influence of modern civilizations. Nevertheless, the analysis of the earliest cases of human conflict does not produce an unambiguous answers. Large differences in patterns and intensity of warfare occur even on a regional scale. Moreover, it is almost impossible to fit all existing data into one generalized theoretical model. Therefore, an alternative research perspective should be adopted; the one, which treats organized violence as a part of sophisticated network of social, economical and ideological factors which constitute the very own identity of a prehistoric society. This identity must always be taken into account when dealing with the problem of the origins of warfare.

Written by Rafat Skrzyniecki 